\title{
Can non-timber forest products solve livelihood problems? A case study from Periyar Tiger Reserve, India
}

\author{
Sanjay Gubi and Douglas C. MacMillan
}

\begin{abstract}
Collection of non-timber forest products (NTFPs) has been promoted in India as a strategy to aid wildlife conservation whilst simultaneously alleviating poverty, and recent legislation now gives communities living within protected areas the legal right to collect NTFPs. However, research on the financial rewards from NTFP collection and its contribution to sustainable development is equivocal. In a case study in the Periyar Tiger Reserve, India, we examined whether NTFP collection can solve livelihood problems by analysing revenues obtained from various NTFP species, estimating the economic returns to collectors from various social backgrounds, and exploring the attitudes of collectors towards their profession. We found that black damar resin from the tree Canarium strictum (61.3\%) and mace from Myristica spp. (35.5\%) were the most commonly collected NTFPs, and the most valuable NTFPs were honey from Apis cerana indica (USD $4.12 \mathrm{~kg}^{-1}$ ), cardamom Elettaria cardamomum (USD $3.67 \mathrm{~kg}^{-1}$ ) and Myristica spp. (USD $2.77 \mathrm{~kg}^{-1}$ ). Mean daily revenue from NTFP collection was USD $3.15 \pm$ SD 4.19 day $^{-1}$, and the lowest daily revenues were earned by part-time collectors with low socio-economic status such as migrants, forest-dwellers or those without access to agricultural land. Most collectors (82\%) did not wish to continue harvesting NTFPs if alternative livelihoods from agriculture could be provided, and none wanted their children to be NTFP collectors. Our findings suggest that, with respect to social justice, poverty alleviation and environmental sustainability, the role of NTFP collection in sustainable development is questionable.
\end{abstract}

Keywords Forest economics, India, livelihoods, NTFP, Periyar Tiger Reserve, poverty alleviation.

\section{Introduction}

Tropical forests provide a large number of products I such as fruit, seed, resin, medicine, wildlife meat and

SANJAy Gubbi ${ }^{*}$ (Corresponding author) Wildlife Conservation Society-India Program, Centre for Wildlife Studies, 1669, 31st Cross, 16th Main, Banashankari 2nd Stage, Bengalooru 560 082, India. E-mail gubbi@wcsindia.org

Douglas C. MacMillan Durrell Institute of Conservation and Ecology, University of Kent, Canterbury, CT2 7NR, Kent, UK.

${ }^{*}$ Also at: Durrell Institute of Conservation and Ecology, University of Kent, Canterbury, CT2 7NR, Kent, UK.

Received 18 June 2007. Revision requested 16 October 2007. Accepted 7 January 2008. by-products defined as non-timber forest products (NTFPs). It has been proposed that NTFP extraction can contribute positively to sustainable forestry management because it provides tangible economic benefits to poor rural communities whilst simultaneously conserving biodiversity (Peters, 1989; Shahabuddin \& Prasad, 2004; Kaushal \& Melkani, 2005; Mahapatra et al., 2005). In India for example, sustainable harvesting and management of NTFP extraction, together with improved market structures, have been promoted as a strategy to aid poverty alleviation and wildlife conservation simultaneously (Mahapatra \& Mitchell, 1997; Shaanker et al., 2004a, 2004b; Hiremath, 2004; Mahapatra et al., 2005; Shanker et al., 2005).

However, there is evidence that such positive benefits from NTFP extraction may be more elusive than first thought. Examples from India have demonstrated that excessive commercial harvesting of NTFPs can denude forest ecosystems by destructive collection practices for valued target species such as Garcinia gummi-gutta, Phyllanthus indofischeri, Emblica officinalis, Boswellia serrata and Sterculia urens (Tiwari, 1995; Bhattacharya et al., 2002; Ganesan, 2003; Rai \& Uhl, 2004; Shaanker et al., 2004a). There is also a link between NTFP collection and illegal activities, including bushmeat hunting and poaching, although the nature of this relationship is poorly understood and documented (Kaul et al., 2004). With legislation in India (The Scheduled Tribes and Other Traditional Forest Dwellers (Recognition of Forest Rights) Act 2006) giving the right, from 31 December 2007, of NTFP collection to communities living within forests, even in protected areas (Kothari, 2005; Prabhu, 2005), there is an urgent need to investigate the role of NTFPs in rural development.

Although various studies in India have highlighted the contribution of NTFPs to household income we still lack understanding of how socio-cultural status can determine income from NTFPs (Shahabuddin \& Prasad, 2004). This is especially important in India where access to NTFPs is controlled by the Government (Gadgil \& Guha, 1992; Rangarajan, 2001) but actual forest use is often determined by various cultural, political and economic background factors (Kumar, 2002; Rai \& Uhl, 2004, Shahabuddin \& Prasad, 2004). Here we focus on which factors determine the financial returns from NTFP collection using a case study in the Periyar Tiger Reserve, in the state of Kerala in southern India. In particular we explore the relationship between financial returns from NTFPs and the social, economic and cultural background of collectors, to 


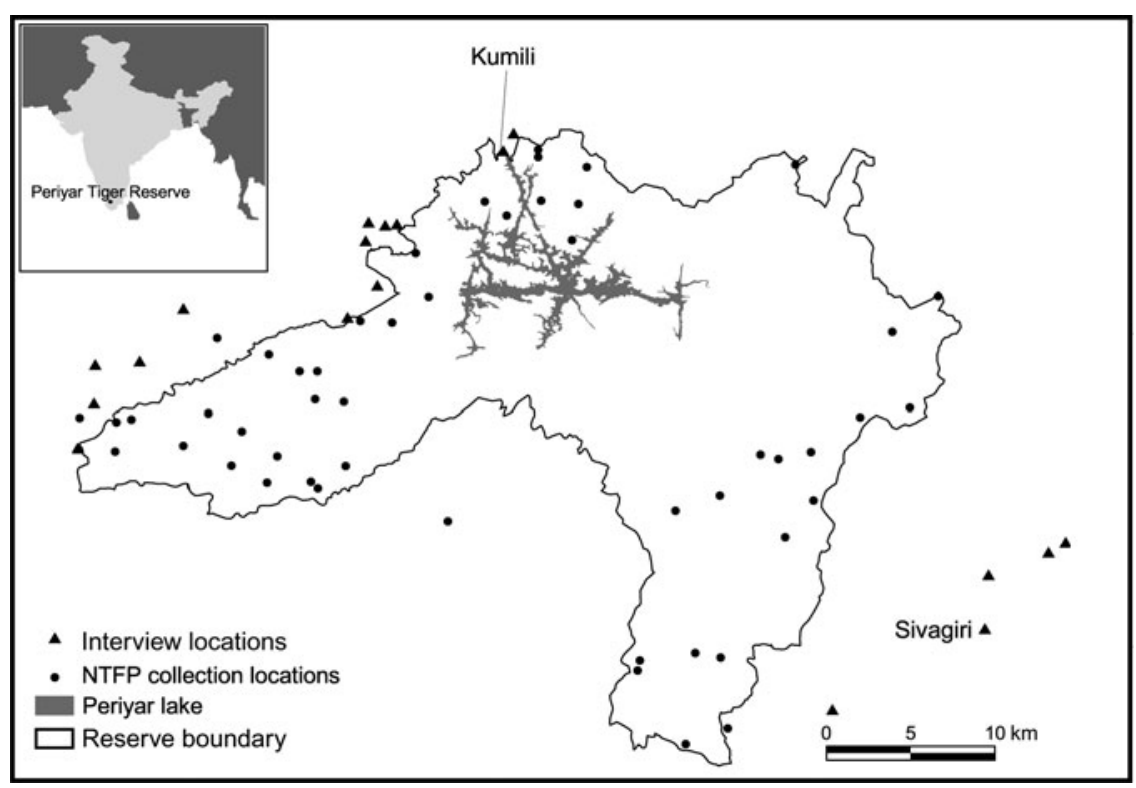

FIG. 1 Locations where NTFPs were harvested in Periyar Tiger Reserve, as reported by the collectors, and where we interviewed collectors. Inset shows location of the Reserve in southern India. understand the potential contribution of NTFP collection to solving livelihood problems.

\section{Study area}

The study was carried out in and around the $777 \mathrm{~km}^{2}$ Periyar Tiger Reserve in the state of Kerala, southern India (Fig. 1). The area forms part of the Western Ghats, which is recognized for its exceptionally rich biodiversity (Myers et al., 2000) and is important for threatened flagship species such as the tiger Panthera tigris tigris (Dinerstein et al., 2006) and elephant Elephas maximus. The Reserve has an altitudinal range of 750-1,500 m, average total annual rainfall of $c$. $2,500 \mathrm{~mm}$, humidity and temperature ranges of $60-85 \%$ and $15-31^{\circ} \mathrm{C}$, respectively, and forest types are tropical evergreen and semi-evergreen (74.6\%) and moist deciduous (12.7\%; KFD, 2001, 2003). The plant species of these forests offer a number of opportunities for NTFP collection.

Approximately 225,000 people live within $2 \mathrm{~km}$ of the Reserve boundary (KFD, 2001), and to varying extents these communities depend, directly and indirectly, on the natural resources of the Reserve through NTFP harvesting, timber smuggling, livestock grazing, tourism and pilgrimage, and narcotic cultivation (World Bank, 1996). The land surrounding the Reserve is intensively farmed, mostly as cash crop plantations for tea, rubber, cardamom Elettaria cardamomum and coffee, providing employment to many people.

\section{Methods}

Survey data were collected between May and July 2006 through questionnaires that included a mixture of open and closed response questions. Sampling was conducted at the household level, as this constitutes the basic unit of shared economic production and resource utilization within the study area. For communities inside and outside Periyar Tiger Reserve only those people perceived to have some dependency on NTFP income were selected from village lists.

All interviews $(n=73)$ were conducted with the full willingness of the respondents, who were assured of anonymity to increase the chances that they would provide genuine answers (Henerson et al., 1987). Questionnaires were conducted in Malayalam and in Tamil with the help of two interpreters who were aware of conservation issues. Interviews took 20-40 minutes. The data collected included information on NTFPs harvested and their quantities, together with demographic information of the collector (age, gender, origin, highest level of formal education, land holding and community background). Respondents who did not reside within the state of Kerala or whose first language was not Malayalam or who had migrated from other states, were categorized as migrants.

NTFP species, quantity collected, locations of harvests, and the final sale price for recent collection trips were elicited from respondents. Location of harvest was established by triangulating information from respondents, Forest Department sources and our field observations. The location of respondents' residences were recorded using a global positioning system, and distance of the house to the collection location was extracted using the geographical information system MapInfo (MapInfo Corporation, Troy, USA) and Survey of India 1:50,000 maps.

The total revenue generated by each collecting trip was calculated from the quantity of NTFP collected and the 
TABLE 1 Percentage of respondents who collected 13 NTFPs (ranked from highest to lowest percentage), with mean quantity collected per trip, and mean price received per unit collected.

\begin{tabular}{|c|c|c|c|c|}
\hline Species & $\begin{array}{l}\text { Part } \\
\text { collected }\end{array}$ & $\begin{array}{l}\% \text { of respondents } \\
\text { who collected }\end{array}$ & $\begin{array}{l}\text { Mean quantity } \\
\text { collected per trip }\end{array}$ & $\begin{array}{l}\text { Mean price per unit } \\
\text { (range), USD }\end{array}$ \\
\hline Black damar Canarium strictum & Resin & 61.3 & $24.16 \mathrm{~kg}$ & $0.88(0.45-1.36) \mathrm{kg}^{-1}$ \\
\hline Nutmeg Myristica spp. & Mace & 35.5 & $11.32 \mathrm{~kg}$ & $2.77(0.68-3.75) \mathrm{kg}^{-1}$ \\
\hline Cardomom Elettaria cardamomum & Pod & 29.0 & $4.56 \mathrm{~kg}$ & $3.67(0.57-6.81) \mathrm{kg}^{-1}$ \\
\hline Honey from Apis dorsata & Honey & 29.0 & $6.171^{\circ}$ & $0.98(0.68-1.19) 1^{-1}$ \\
\hline Honey from Apis cerana indica & Honey & 25.8 & 2.791 & $4.12(1.65-6.8) \mathrm{l}^{-1}$ \\
\hline Thatching grass Themeda cymbaria & Grass & 12.9 & 125 stalks & 1.59 per 100 stalks $(1.25-2.27)$ \\
\hline Cinnamon Cinnamomum malabatrum & Bark & 9.7 & $37.5 \mathrm{~kg}$ & $0.85(0.62-1.18) \mathrm{kg}^{-1}$ \\
\hline Malabar tamarind Gracinia gummi-gatta & Fruit & 9.7 & $18.33 \mathrm{~kg}$ & $0.60(0.23-0.90) \mathrm{kg}^{-1}$ \\
\hline Indian gooseberry Emblica officinalis & Fruit & 9.7 & $21.17 \mathrm{~kg}$ & $0.10(0.09-0.11) \mathrm{kg}^{-1}$ \\
\hline Bamboo reed Ochlandra travancorica & Reed & 3.2 & 100 reeds & 1.13 per 100 reeds $(0.82-1.34)$ \\
\hline Pepper Piper nigrum & Pod & 3.2 & $7.5 \mathrm{~kg}$ & $0.34(0.31-0.38) \mathrm{kg}^{-1}$ \\
\hline Ginger Zingiber spp. & Tuber & 3.2 & $7.5 \mathrm{~kg}$ & $0.22 \mathrm{~kg}^{-1}$ \\
\hline Soapnut Acacia sinuata & Pod & 3.2 & $10 \mathrm{~kg}$ & $0.22 \mathrm{~kg}^{-1}$ \\
\hline
\end{tabular}

price achieved by the collector. To compare the financial returns from NTFP collection with other alternative local economic activities on a per unit effort basis (e.g. the daily wage for labouring in a tea plantation), the average revenue per day of a trip was estimated by dividing total revenue by the number of days spent on the trip. Revenue earned from NTFP was recorded in Indian rupees (INR) and converted to USD using USD $1=$ INR 44 , the prevailing rate at the time. In addition, respondents were asked about their willingness to continue NTFP collection as a profession for themselves and for their children. If they were unwilling to continue NTFP collection as a profession they were asked what alternative profession they would prefer.

General linear regression analysis was performed to determine which independent variables (gender, age, local or migrant, level of formal education, possession of agricultural land or not, NTFP collection for livelihood or additional income, forest-dwelling community or not), individually or in combination, best explained average daily revenue obtained by the respondents. SPSS $v$. 14.o (SPSS, Chicago, USA) was used for all statistical analyses.

\section{Results}

Of the 73 respondents $13 \%$ were female and $88 \%$ male, most ( $71 \%)$ were non-forest dwelling communities as opposed to forest-dwellers (29\%), and 52\% were migrants and the rest (48\%) local. The mean age of respondents was $42 \pm$ SD 9.88 years (range $23-60$ ), and while many (58\%) had attained some level of formal education, relatively few (19\%) had attained secondary education. Mean household size was 4.5 \pm SD 1.56 people (range 1-9). Only a quarter of respondents owned agricultural land and the average landholding was only $0.32 \pm$ SD 0.24 ha (range $0.04-0.80$ ha). For $61 \%$ of respondents NTFPs were the main source of livelihood, and $39 \%$ collected NTFPs on a part-time basis to supplement their income.

Collectors spent an average of $6.2 \pm$ SD 4.84 days per trip in the Reserve (range 1-20). On average, they travelled $11 \pm$ SD $8.6 \mathrm{~km}$ per trip (range $0.48-38.11 \mathrm{~km}$ ). Length of a trip depended, in part, on the location of residence, and NTFP collectors from the neighbouring state of Tamilnadu covered the greatest distances and expended the most time (an average of $38 \mathrm{~km}$ and 20 days per trip).

TABLE 2 Results of regression of average daily revenue from NTFP collection against four independent variables describing the socioeconomic characteristics of individual collectors.

\begin{tabular}{lclll}
\hline & \multicolumn{2}{c}{ Unstandardized coefficients } & \multicolumn{2}{c}{ Standardized coefficients } \\
& $\mathrm{B}$ & $\mathrm{SE}$ & $\mathrm{B}$ & $\mathrm{P}$ \\
\hline Constant & 6.247 & 1.731 & & 0.001 \\
Purpose $^{1}$ & -3.401 & 1.164 & -.401 & 0.007 \\
Origin $^{2}$ & 3.771 & 1.451 & 0.456 & 0.015 \\
Community $^{3}$ & -6.152 & 1.622 & -.676 & 0.001 \\
Land holding $^{4}$ & 5.674 & 1.444 & 0.601 & 0.001 \\
\hline
\end{tabular}

${ }^{1}$ Whether NTFPs were collected for livelihood or as an income supplement

${ }^{2}$ Origin, i.e. local or migrant from neighbouring states

${ }^{3}$ Whether from a forest-dwelling or other community

${ }^{4}$ Whether possessed agricultural land 
In total, respondents collected 33 NTFP species. Table 1 provides the percentage of respondents collecting the 13 most economically important species, the average quantity collected, and the average and range of prices obtained. Commercial harvesting of the resin black damar, for use in varnish and the perfume industry, from the tree Canarium strictum was the most commonly collected NTFP, followed by mace from Myristica spp., which is used in the aromatic industry or as a natural dye. The most valuable NTFP was the honey of Apis cerana indica, followed by cardamom, and mace from Myristica spp.. There was considerable range in price obtained for some products. For example, cardamom was sold for as little as USD $0.57 \mathrm{~kg}^{-1}$ and as high as USD $6.81 \mathrm{~kg}^{-1}$.

Average revenue was USD $3.15 \pm$ SD 4.19 day $^{-1}$, varying widely (USD $0.27-23.63 \mathrm{day}^{-1}$ ). Collectors whose livelihood was largely dependent on NTFPs earned more, averaging USD $3.88 \mathrm{day}^{-1}$, whereas part-time collectors earned on average USD $1.99 \mathrm{day}^{-1}$. Daily returns were directly determined by distance travelled, quantity collected, and price obtained but we considered that other socio-economic and cultural factors may have been influencing revenues. Therefore, we examined the influence on average daily revenue of seven variables, using general linear regression analyses. The independent variables were (1) gender; (2) origin of the respondent (local or migrant); (3) age of the respondent (categorized into age groups); (4) level of formal education (categorized as none, primary, secondary); (5) whether or not they possessed agricultural land; (6) purpose of collection (livelihood or part-time income supplement); and ( 7 ) community of origin (forest-dwelling or not).

When considered in combination, the variables that best explain average daily revenue are origin, community, agricultural land holding, and purpose of collection (adjusted $R^{2}=0.470, F$-test $\mathrm{P}=0.001$; Table 2). Respondents with a lower average daily revenue tend to be part-timers with lower socio-economic status such as migrants, forest-dwellers or those without access to agricultural land. Hence, collectors from low income households with less economic opportunities achieve lower returns from NTFP collection than others.

The majority (82\%) of the respondents would prefer not to continue the profession of NTFP collection, with many respondents preferring agricultural land (41\%) or livestock $(11 \%)$ as an alternative livelihood source. A smaller number (12\%) would accept any job, and $11 \%$ would prefer to have small businesses. A few $(7 \%)$ were willing to work as forest guards and the remainder (18\%) were not sure about the kind of job they wanted. None of the respondents wanted their children to take up NTFP collection as a profession.

\section{Discussion}

The mean daily revenue from NTFP collection was higher than the average agricultural wage labour, which is $c$. USD 2.09 day $^{-1}$ in the state of Kerala (DES, 2003) and USD 1.38 day $^{-1}$ in the neighbouring state of Tamilnadu (DES, 2005). However, economic returns from NTFP collection were variable and highly influenced by socio-economic status. For example, many migrants and forest-dwellers earn $<$ USD 1 day $^{-1}$ from NTFP collection. This is partly because they are not well equipped in terms of social status and education to deal with middlemen, and hence can be exploited, but also because they are less able to add value to their collection because of their poorly developed skills and restricted access to the resources required to invest in storage, processing, and marketing (Bhattacharya et al., 2002; Mahapatra et al., 2005).

Another factor is political patronage. NTFP harvesting is illegal and, with little local political influence, migrants face a much higher risk of capture and prosecution by the Forest Department, especially when they harvest high value NTFPs such as Cinnamomum malabatrum. In contrast, better placed local people enjoy a degree of protection from local political leaders and can afford to take the risk of being caught and prosecuted for illegally harvesting commercially higher value NTFPs, which is considered a more serious offence than harvesting lower value NTFPs (Bawa \& Gadgil, 1997). These findings are consistent with other studies showing that wealthier households from higher classes in society tend to reap greater benefits from NTFP collection than poorer households (Kumar, 2002; Rai \& Uhl, 2004; Mahapatra et al., 2005). Other studies also highlight the importance of land tenure security, local institutions, and social dynamics to NTFP incomes and unsustainable extraction practices (Momberg et al., 2000; Rai \& Uhl, 2004; Rai, 2007).

Overall, we believe that NTFP collection, far from being a potential solution in a development context (Mahapatra \& Mitchell, 1997; Reddy \& Chakravarty, 1999; Arnold \& Pérez, 2001; Bhattacharya \& Hayat, 2004; Hiremath, 2004; Pandit \& Thapa, 2007) may threaten biodiversity and help enforce economic and social disparities, especially in India, where protected areas are surrounded by land with human densities $>300 \mathrm{~km}^{-2}$ (Rodgers et al., 2003).

NTFP collection in protected areas could have significant negative ecological impacts. Although impacts have been little studied in India (Shaanker et al., 2004a; Shahabuddin \& Prasad, 2004), studies in some areas have reported the damaging impacts of harvesting on ecosystem functions that could negatively affect biodiversity (Sinha, 2000; Sinha \& Bawa, 2002; Pant, 2003; Rai \& Uhl, 2004; Shaanker et al., 2004b). Ved et al. (2001), for example, documented 154 species of medicinal plants that have become rare and threatened by extraction pressures in southern India. These impacts could intensify with the introduction of new technology, access to new markets, and the possible breakdown of social and religious restrictions (Bawa \& Gadgil, 1997; Sinha \& Bawa, 2002; Kala et al., 2005). 
Encouragement and support of NTFP collection from protected areas could also have significant negative impacts on tiger and other threatened species. Although the overall link between NTFP exploitation and animal communities is poorly explored (Shahabuddin \& Prasad, 2004), commercialization of forest products as a conservation strategy in protected areas could increase the negative impacts of more intensive harvesting (Green \& Minkowski, 1977; Prasad, 2001; Muddappa, 2001), and reliance on more destructive practices such as burning and timber-cutting (Madhusudhan \& Karanth, 2000; Saha, 2002; Shahbuddin \& Prasad, 2004). NTFP collection in a protected area may also be directly connected to illegal collateral activities such as poaching, as it provides a legitimate excuse for human presence (Madhusudhan \& Karanth, 2000; Peres \& Lake, 2003).

Our study suggests that NTFP as a development mechanism for poor communities may have disadvantages. Firstly, those collectors most in need of income support from NTFPs are least able to benefit from an NTFP-based development strategy as they have the poorest developed skills, lack resources to store, process and market their produce, and face prejudice and unfair treatment because of their social status. Secondly, it can expose collectors and their dependents to widely fluctuating incomes because of price variations in local and global markets (Arnold \& Pérez, 2001; Rai \& Uhl, 2004; Gopalakrishnan et al., 2005) and extremes in seasonal and biological production (Mahapatra et al., 2005). Thirdly, in the long-term there is also the risk that the price for some NTFPs will decline as factory-made alternatives such as plastic containers for bamboo and reed baskets, and plastic for rattan furniture, become more widely available. Fourthly, the institutions and practices for monitoring harvesting rates and capacity building for commercial NTFP production require more time and resources than other development options (Barrett \& Arcese, 1998; Ballabh et al., 2002; Gubbi, 2006).

Finally, there would appear to be little desire among the collectors interviewed in this study to continue with NTFP collection as a profession. This is hardly surprising as the work is hard and collectors risk danger from tiger, elephant, sloth bear and other wildlife, and from the steep and rough terrain they must traverse. Furthermore, all respondents, including forest-dwellers, stated they did not want their children to continue with NTFP collection as it is a hard life, and expressed the desire that their children receive education and find alternative employment.

As nearly half of the respondents were willing to shift to agriculture-based professions, direct measures to encourage this, such as the provision of agricultural land by the Government or civil society, would be a more sustainable alternative to NTFP in both ecological and human terms. There are a number of successful agriculture-based projects, although small in number, implemented in India, by both government and civil society, in which local communities have benefited (Gubbi, 2003; Karanth et al., 2005; Karanth \& Karanth, 2007) whilst also reducing their dependence on NTFPs (Shanker et al., 2005). Formal and non-formal education among collectors could also improve chances of alternative employment and lead to reduced dependency on forests (Gunatilake, 1998; Hegde \& Enters, 2000; Tessema, 2003; Xu et al., 2006).

It may be possible that NTFP collection can find a niche role in development through ecotourism, in which collection activities are regulated and income is largely generated by providing services to tourists rather than from ecologically damaging extraction. Tourism activities, such as spice plantation visits are now underway in the northern part of Periyar Tiger Reserve, and similar opportunities such as rubber plantation visits involving NTFP collectors from the western part of the Reserve could be explored for other areas. However, it is important that the most socially disadvantaged groups are actively targeted in any development initiative. This has proved difficult in India for sociocultural reasons. For example, in a development programme for cinnamon bark collectors carried out under an Integrated Conservation and Development Project in the Periyar Tiger Reserve, only one out of 21 participants in a high value tourism venture, which brought good tips, were from a disadvantaged group. In contrast, an ecotourism enterprise run entirely by poorer forest-dwelling communities under the same Programme brought less revenue to the eco-development committee that runs the enterprise and the guides received lower tips (S. Gubbi, pers. obs.).

In conclusion, our research suggests that NTFP collection is unlikely to generate positive outcomes for biodiversity conservation or poverty alleviation. The new laws giving rights of land and resource use, including NTFP collection, to communities living within forests and protected areas (Kothari, 2005; Prabhu, 2005), are therefore probably misguided in terms of livelihoods and harmful to conservation in protected areas (Karanth \& Bhargav, 2005; Dang, 2005). We suggest that the Indian government considers provision of alternative farm-based livelihoods and investment in improved access to education for collectors and their families. Further research is, however, required to compare NTFP revenues within other protected areas to understand further the social, economic and legal factors affecting incomes from NTFPs. Results of such studies will further strengthen the case for or against NTFP collection as a mechanism for alleviating poverty and supporting wildlife conservation.

\section{Acknowledgements}

We thank the respondents who took part in the survey, K.U. Karanth, S. Kumar, A. Kumar, S. Srinivas and B. 
Hegde of the Wildlife Conservation Society-India Program, N. Leader-Williams and M. Linkie of of Durrell Institute of Conservation and Ecology (DICE), UK, V. Gopinath, B. Thomas, P. Mahanti, M.L. Thomas, J. Zacharias and S. Francis of Kerala Forest Department, and R. Pillai, M. Balasubramaniam, A. Veeramani, A. Bashir, Sebastain, M.B. Anil, Sasikala and Jaya of the Periyar Foundation. M.D. Madhusudhan and K. Karanth provided useful inputs. Funding was provided through a WCS Graduate Fellowship and C.V. Starr Graduate Fellowship in Tiger Conservation, the Wildlife Conservation Society-India Program, and the Centre for Wildlife Studies, 21st Century Tiger and DICE. Kerala State Forest Department provided the necessary permission and support. We thank two anonymous referees whose comments improved the manuscript.

\section{References}

Arnold, J.E.M. \& Perez, M.R. (2001) Can non-timber forest products match tropical forest conservation and development objectives? Ecological Economics, 39, 437-447.

Ballabi, V., Balooni, K. \& Dave, S. (2002) Why local resources management institutions decline: a comparative analysis of van (forests) panchayats and forest protection committees in India. World Development, 30, 2153-2167.

Barrett, C.B. \& Arcese, P. (1998) Wildlife harvest in integrated conservation and development projects: linking harvest to household demand, agricultural production, and environmental shocks in the Serengeti. Land Economics, 74, 449-465.

BAWA, K.S. \& GADGIL, M. (1997) Ecosystem services in subsistence economics and conservation of biodiversity. In Nature's Services: Societal Dependence on Natural Ecosystems (ed. G.C. Daily), pp. 295-310. Island Press, Washington, DC, USA.

Bhattacharya, P. \& Hayat, S.F. (2004) Sustainable NTFP management for rural development: a case from Madhya Pradesh, India. International Forestry Review, 6, 161-168.

Bhattacharya, P., Joshi, B., Bhagat, N.K. \& Hayat, F. (2002) Sustainable harvesting of kullu (Sterculia urens) gum. Indian Institute of Forest Management Newsletter, $1 \& 2,3-5$.

D ANG, H. (2005) The end of conservation. Seminar, 552, 50-54. DES (Department of Economics and Statistics) (2003) Economic Review 2003. Government of Kerala, Thiruvananthapuram, India.

DES (Department of Economics and Statistics) (2005) Season and Crop Report 2004-2005. Government of Tamilnadu, Chennai, India.

Dinerstein, E., Loucks, C., Heydlauff, A., Wikramanayake, E., Bryja, G., Forrest, J. et al. (2006) Setting Priorities for the Conservation and Recovery of Wild Tigers: 2005-2015. A User's Guide. WWF, WCS, Smithsonian, and NFWF-STF, Washington, DC and New York, USA.

Gadgil, M. \& Guha, R. (1992) This Fissured Land: An Ecological History of India. Oxford University Press, New Delhi, India.

Ganesan, R. (2003) Identification, distribution and conservation of Phyllanthus indofischeri, another source of Indian gooseberry. Current Science, 84, 1515-1518.

Gopalakrishnan, C., Wickramasinghe, W.A.R., Gunatilake, H.M. \& Illukpitiya, P. (2005) Estimating the demand for nontimber forest products among rural communities: a case study from the Sinharaja rain forest region, Sri Lanka. Agroforestry Systems, 65, 13-22.

Green, S. \& Minkowski, K. (1977) The Lion-tailed macaque and its South Indian rainforest habitat. In Primate Conservation (eds P. Rainer \& G.H. Bourne), pp. 290-338. Academic Press, New York, USA.

Guввi, S. (2003) Mitigating encroachment problems in Kudremukh National Park, India. Oryx, 37, 402-403.

Gubi, S. (2006) Tiger habitats and Integrated Conservation and Development Projects: a case study from Periyar Tiger Reserve, India. MSc thesis, University of Kent, Canterbury, UK.

Gunatilake, H.M. (1998) The role of rural development in protecting tropical rainforests: evidence from Sri Lanka. Journal of Environmental Management, 5, 273-292.

Hegde, R. \& Enters, T. (2000) Forest products and household economy: a case study from Mudumalai Wildlife Sanctuary, Southern India. Environmental Conservation, 27, 250-259.

Henerson, M.E., Morris, L.L. \& Fitz-Gibbon, C.T. (1987) How to Measure Attitudes. SAGE Publications, Newbury Park, USA.

Hiremath, A.J. (2004) The ecological consequences of managing forests for non-timber productrs. Conservation \& Society, 2, 211216.

Kala, C.P., Farooquee, N.A. \& Dhar, U. (2005) Traditional uses and conservation of timur (Zanthoxylum armatum) through social institutions in Uttaranchal Himalaya, India. Conservation \& Society, 3, 224-230.

Karanth, K.K., Curran, L.M. \& Reuning-Scherer, J.D. (2005) Village size and forest disturbance in Bhadra Wildlife Sanctuary, Western Ghats, India. Biological Conservation, 128, 147-157.

Karanth, K.U. \& Bhargav, P. (2005) De-fragmenting nature. Seminar, 552, 59-62.

Karanth, K.U. \& Karanth, K.K. (2007) Free to move: conservation and voluntary resettlements in the Western Ghats of Karnataka, India. In Protected Areas and Human Displacement: A Conservation Perspective (eds K.H. Redford \& E. Fearn), pp. 4859. Wildlife Conservation Society, New York, USA.

KaUl, R., Hilaluddin, Jandrotia, J.S. \& McGowan, P.J.K. (2004) Hunting of large mammals and pheasants in the Indian western Himalaya. Oryx, 38, 426-431.

KaUshal, K.K. \& MeLKani, V.K. (2005) India: achieving the Millennium Development Goals through non-timber forest products. International Forestry Review, 7, 128-134.

KFD (Kerala Forest Department) (2001) Management Plan for Periyar Tiger Reserve. Government of Kerala, Thiruvananthapuram, India.

KFD (Kerala Forest Department) (2003) India Eco-Development Project: Building Social Capital for Conservation. Kerala Forest Department, Periyar Tiger Reserve, India.

Kothari, A. (2005) Bungle in the jungle. Seminar, 552, 63-69. KUMAR, S. (2002) Does "participation" in common pool resource management help the poor? A social cost-benefit analysis of joint forest management in Jharkhand, India. World Development, 30, $763-782$.

Madhusudan, M.D. \& Karanth, K.U. (2000) Hunting for an answer: is local hunting compatible with wildlife conservation in India? In Hunting for Sustainability in Tropical Forests (eds J.G. Robinson \& E. Bennet), pp. 339-355. Columbia University Press, New York, USA.

Mahapatra, A. \& Mitchell, C.P. (1997) Sustainable development of non-timber forest products: implication for forest management in India. Forest Ecology and Management, 94, 15-29.

Mahapatra, A.K., Albers, H.J. \& Robinson, E.J.Z. (2005) The impact of NTFP sales on rural households' cash income in India's dry deciduous forest. Environmental Management, 35, 258-265. 
Momberg, F., Puri, R. \& Jessup, T. (2000) Exploitation of gaharu, and forest conservation efforts in the Keyan Mentarang National Park, East Kalimantan, Indonesia. In People, Plants, and Justice: The Politics of Nature Conservation (ed C. Zerner), pp. 259-284. Columbia University Press, New York, USA.

Mudappa, D. (2001) Ecology of the brown palm civet Paradoxurus jerdoni in the tropical rainforests of the Western Ghats, India. $\mathrm{PhD}$ thesis, Bharathiar University, Coimbatore, India.

Myers, N., Mittermeier, R.A., Mittermeier, C.G., De FonsecA, G.A.B. \& Kent, J. (2000) Biodiversity hotspots for conservation priorities. Nature, 403, 853-858.

Pandit, B.H. \& Thapa, G.B. (2007) Poverty and resource degradation under different common forest resource management systems in the Mountains of Nepal. Society \& Natural Resources, $17,1-16$.

Pant, A. (2003) Ecological Analysis of the Satpura Conservation Area Landscape through Stratified Field Sampling and Remotely Sensed Data. Map India Conference 2003. Department of Science and Technology, New Delhi, India.

Peres, C.A. \& LAKE, I.R. (2003) Extent of nontimber resource extraction in tropical forests: accessibility to game vertebrates by hunters in the Amazon basin. Conservation Biology, 17, 521-535.

Peters, C.M. (1989) Valuation of an Amazonian rainforest. Nature, $339,655-656$

PrABHU, P. (2005) The right to live with dignity. Seminar, 552, 14-19.

PRASAD, S. (2001) Fruit removal, seed dispersal and demography of Emblica officinalis at Rajaji National Park, Uttaranchal. MSc thesis, Wildlife Institute of India, Dehradun, India.

RAI, N.D. (2007) The ecology of income: can we have both fruit and forest? In Making Conservation Work (eds G. Shahabuddin \& M. Rangarajan), pp. 142-162. Permanent Black, Ranikhet, India.

RAI, N.D. \& UHL, C.F. (2004) Forest product use, conservation and livelihoods: the case of Uppage fruit harvest in the Western Ghats, India. Conservation \& Society, 2, 289-313.

Rangarajan, M. (2001) India's Wildlife History. Permanent Black, New Delhi, India

RedDy, S.R.C. \& Chakravarty, S.P. (1999) Forest dependence and income distribution in a subsistence economy: evidence from India. World Development, 27, 1141-1149.

Rodgers, A., Hartley, D. \& Bashir, S. (2003) Community approaches to conservation: some comparisons from Africa and India. In Battles Over Nature: Science and the Politics of Conservation (eds V. Saberwal \& M. Rangarajan), pp. 324-382. Permanent Black, New Delhi, India.

SAHA, S. (2002) Anthropogenic fire regime in a deciduous forest of central India. Current Science, 82, 1144-1147.

Shatnker, R.U., Ganeshaiah, K.N., Krishnan, S., Ramya, R., Menra, C., Aravind, N.A. et al. (2004a) Livelihood gains and ecological costs of non-timber forest product dependence: assessing the roles of dependence, ecological knowledge and market structure in three contrasting human and ecological settings in south India. Environmental Conservation, 31, 242-253.

Sha anker, R.U., Ganeshaiah, K.N., Rao, M.N. \& Aravind, N.A. (2004b) Ecological consequences of forest use: from genes to ecosystem - a case study in the Biligiri Rangaswamy Temple Wildlife Sanctuary, South India. Conservation \& Society, 2, $347-363$.

Shahabuddin, G. \& Prasad, S. (2004) Assessing ecological sustainability of non-timber forest produce extraction: the Indian scenario. Conservation \& Society, 2, 235-250.

Shanker, K., Hiremath, A. \& BAWA, K. (2005) Linking biodiversity conservation and livelihoods in India. PLoS Biology, 3, e394.

SinHA, A. (2000) Sustainability of fruit extractions from two nontimber forest product tree species, Phyllanthus emblica and P. indofischeri, in the forests of south India. PhD thesis, University of Massachusetts, Boston, USA.

SinHA, A. \& B AWA, K.S. (2002) Harvesting techniques, hemiparasites and fruit production in two non-timber forest tree species in south India. Forest Ecology and Management, 168, 289-300.

Tessema, M.E. (2003) Perceptions of local communities towards wildlife and protected areas of Ethiopia. MSc thesis, University of Kent, Canterbury, UK.

Tiw A RI, K.P. (1995) Collection of aonla (Emblica officinalis) fruits from forest: an impact assessment. Vainiki Sandesh, $14,1-5$.

Ved, D.K., Prathima, C.L., Mortan, N. \& Shankar, D. (2001) Conservation of India's medicinal plant diversity through a novel approach for establishing a network of in situ gene banks. In Forest Genetic Resources: Status, Threats and Conservation Strategies (eds R.U. Shaanker, K.N. Ganeshaiah \& K.S. Bawa), pp. 183-195. Oxford and IBH Publications, New Delhi, India.

World BANK (1996) India Ecodevelopment Project. The World Bank, Washington, DC, USA.

Xu, J., Chen, L., Lu, Y. \& Fu, B. (2006) Local people's perceptions as decision support for protected area management in Wolong Biosphere Reserve, China. Journal of Environmental Management, $78,362-372$.

\section{Biographical sketches}

SANJAY GUBBI's research interests are in conservation policies and human impacts on wildlife conservation. He has a keen interest in evidence-based conservation and his current work is focused on conservation of tigers and other wildlife in the Western Ghats of India. Douglas MacMillan is interested in the economics of conservation and development and has a special interest in the design and implementation of economic incentives for sustainable resource use. 